\title{
Emancipatory discourse in the names of children of the present generation: Some attempts of balancing power relations with special reference to Tshivenda naming practices
}

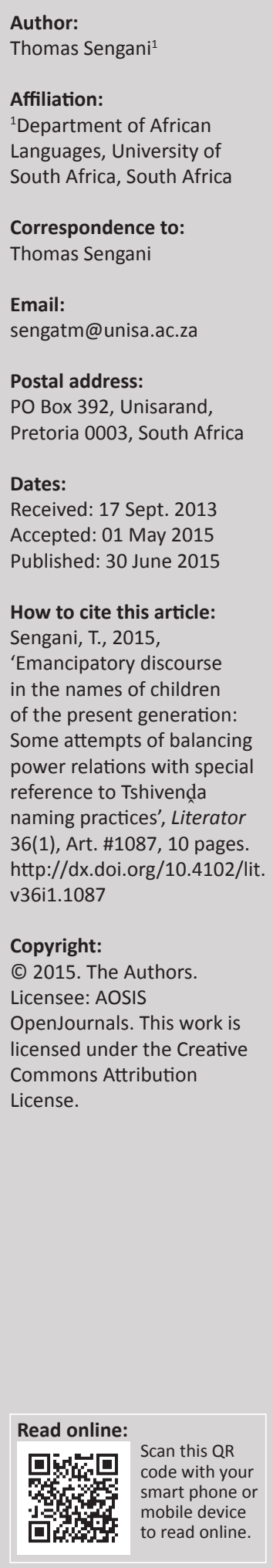

Author:

Thomas Sengan ${ }^{1}$

Correspondence to:

Email:

Postal address:

PO Box 392, Unisarand,

Received: 17 Sept 2013

How to cite this article:

Sengani, T., 2015

Emancipatory discourse

of the present generation:

Some attempts of balancing

reference to Tshivenda

naming practices', Literator

36(1), Art. \#1087, 10 pages.

http://dx.doi.org/10.4102/lit.

Copyright:

(C) 2015. The Authors

Licensee: AOSIS

licensed under the Creative

Commons Attribution
In most African cultures children are given names by the elders, especially by grandmothers. This task is assigned to them as they are seen as custodians of culture, history and heritage. They in turn have over the years used the power bestowed upon them to make critical statements to their children or any other person they disagree with through the names that they give to the family's new-born children. For this reason, there have been silent wars in families and communities. These silent feuds have been difficult to deal with, as any challenge to the elders or their way of doing things is a challenge to tradition, and challenging traditions has historically been unheard of or frowned upon amongst Africans in general. This article intends to demonstrate that, whereas in some cases the elders have continued to give names to their grandchildren which are not so favourable to their parents, over the years parents themselves have used subtle diplomacy to do it on their own instead. The names are, therefore, free from the usual conflicts, quarrels and disagreements that they themselves had to contend with even when all these conflicts have nothing to do with them. They have in the main also tried to pacify the elders or parents by naming their children after their own great-grandparents and other ancestors in order to build bridges.

Bevrydingsdiskoers in die name van die kinders van die huidige geslag: 'n Paar pogings om magsverhoudings te balanseer met spesiale verwysing na Tshivenda naamgewingspraktyke. In die meeste Afrikakulture word kinders name gegee deur senior lede van die familie, meestal die grootmoeders. Hierdie taak word deur hulle verrig omdat hulle gesien word as draers van die kultuur, geskiedenis en nalatenskap. Op hulle beurt het hulle deur die jare die mag wat aan hulle toegeken is, gebruik om kritiese stellings teenoor hulle kinders of enige ander persoon waarvan hulle verskil, te maak, deur name wat hulle aan pasgeborenes toeken. Om hierdie rede was daar voortdurend konfliksituasies binne families en gemeenskappe wat moeilike situasies geskep het. Enige poging wat aangewend is om van senior familielede te verskil, is beskou as ' $n$ aanslag op tradisie, as ongehoord en is dus op neergesien in Afrikagemeenskappe. Hierdie referaat het ten doel om te demonstreer dat nieteenstaande die feit dat grootouers in sommige gevalle steeds voortgaan met naamgewing aan kleinkinders sonder die goedkeuring van die ouers, hul kinders tog op eie stoom voortgaan om hierdie praktyk met subtiele diplomasie toe te pas. Name wat hedendaags gekies word is daarom vry van die gebruiklike konflik, twis en verskille waarmee ouers as kinders moes saamleef terwyl hul self gewoonlik niks daarmee te doen gehad het nie. Kinders wend oor die algemeen 'n poging aan om brûe tussen generasies te bou deur hulle kinders na groot-grootouers asook na geslagte verder terug, te vernoem.

\section{Introduction}

This article intends to look into the problem of power relations that present themselves when children are named by either elders or their parents. It focuses on names as interactional discourse that participants use to speak to each other through the names that are given to new-born babies. African tradition accords the elders the right to name children, but their parents feel that they are directly and indirectly being dictated to and, in turn, would like to use the same process to respond to this. This, therefore, makes names a site of a power struggle between the elders and the younger generation.

Every human being, as well as any object, is associated with a name. Names appear to be small, condensed and seemingly nominal or even predicative elements, and are seen to be very 
common (Sengani 2008). Amongst the Vhavenda, names are not only created to identify their bearers, but are also used to communicate valuable information between the name-givers and their addressees. In other words, the Vhavenda create names by looking at their own environment, history, sociocultural contexts, religion and economy, and then source from their linguistic and cultural knowledge, rules and principles to encode these factors. It is for this reason that whenever a name is created, a discourse that reflects what is observed or experienced is constructed. Foucault (1972:42) defines discourse as 'practices that systematically form the objects of which they speak'. In other words, names may, in terms of structure, appear as linguistic forms, but 'they are social and ideological practices which can govern the ways in which people think, speak, interact, write and behave' as Litosseliti (2010:120) sees it. This, also, is the reason why Fairclough (1989:17) sees discourse as a social practice.

In many communities, naming children has always been the prerogative of the elders (Arno 1994:25). This is because they are seen to have the knowledge and skill to create or record history. As the appointed custodians of culture and heritage, they remind people of events that took place in the past and in the present, and also project into the future. Amongst the Vhavenda, most names encode their history, culture and heritage. According to Tonkin (1965), names are seen as personal facts that express aspirations as well as social and organisational control.

\section{Background}

The set-up in African communities, which includes the Vhavenda, is that when a young man is married, he and his new family, as well as his extended family, will live within the same homestead for some time. The head of the family is his father, but the running of the household is the responsibility of his mother. This being the case, she is the one who gives the womenfolk responsibilities. In most cases, mothers-in-law control the finances, groceries and the distribution of duties. They are the ones who decide on marriage issues and attend to cases where there are no children (Blacking 1964:18-19; Stayt 1931:1988-1989). Whenever there are disagreements with their daughters-in-law or sons, the elders can use naming as a channel to respond to them if they feel that they had been undermined. The names would comment on the relationships between people within the family or extended family.

In African traditions, as amongst the Vhavenda, a child belongs to the community, and as such, his or her name is given to reflect issues within such a community (Arno 1994). For this reason, according to Akinnaso (1980:279-280), the names tend to relate to the environment, history, politics, economy and events within the community. Traditionally, children are named by specific people only, such as the elders or medicine men or women and grandmothers. They are regarded as having the social power and capacity to impose constraints on the younger people's behaviour and thoughts to subject them to the elders. These customs are not violently or overtly imposed, but are legitimised through proverbial sayings which are grounded in the authorial language of the elders. They and they alone have privileged access to valued resources, such as the knowledge surrounding naming. In Tshivenda this ideology is legitimised through expressions such as Dzina la vhakegulu or 'the name of the grandmothers'. Whatever the meaning of the name, it should be taken at face value and should not be questioned because it has been sanctioned by vhakegulu or 'the grandmothers/ elders'. The names, therefore, tend to carry strong ideological assumptions (Kamberelis \& Scott 2004:368). This means that even if a name is insulting or creates an ugly identity, it should be accepted because it was given by experts. This is a strategy where the elders use, as Foucault (1994:140) puts it, 'explicit or tacit regulations and an apparatus', and in the use of these regulations and apparatus, 'one risks giving to one or the other an exaggerated privilege in the relations of power and hence, seeing in the latter only modulations of law and coercion' (Foucault 1994:140).

This is how hegemony comes into play. In the naming of children, there are ceremonies that follow certain procedures, and usually the mothers and fathers are instructed about what to do.

In all this the elders as speakers would be addressing the rest of the group. In this way, they are able to construct a critical discourse and, as speakers with power, they are able to exercise dominance and control and often even abuse their power, although indirectly (Fairclough \& Wodak 1997).

\section{Data}

The names cited and analysed in this article were collected in Pretoria and Venda in Limpopo during 2004, when I was busy with my doctoral studies. I had come across grown-ups and children with Tshivenda names and some from other languages such as Xitsonga, Sotho and the Nguni languages and, following this, decided to interview both name-givers and name-carriers. Their information led me to other people involved in the naming process who were grandparents, parents and younger people. The process involved asking how the names came about or the reasons behind them. The information was written down and the names themselves analysed and the interpretation given was based on the information I had gathered. The gathered information revealed that the names seem to express serious conflicts between the elders (the grandparents) and the parents of the children, but I later noted that the conflicts ran across generations.

\section{Some theoretical background}

Scholars from different schools of thoughts have expressed their views on the meaning of names. The philosopher Mills (1904), cited by Tapscott (1968:80-82), focusing on English names, maintains that names are meaningless. However, a number of scholars such as Frege (1985), Russell (1985), Searle 
(1985) Donnelan (1985) challenged his views, arguing that a name is associated with statements or characteristics or even descriptions befitting the person to whom it is given. Thus, names have what Ziff (1960:93) calls 'information content'. In fact, Tapscott (1968:82) shows that at some stage Mills had agreed that names have an informative content, except that he did not follow-up this agreement.

Of importance, concerning the characteristics of or identifying descriptions of names, is that information content is more prevalent in the case of commemorative names. According to Arno (1994:25), amongst the Lauana of Fiji, children are named after relatives. The meaning of the name and the characteristics associated with it are, in this case, the characteristics that are associated with the name donor. The same has been found amongst the Ovambo, where a child could be given the name of a respected community member. The name donor, according to Saarel-Maunumaa (1999:23), or the name-carrier, is so highly regarded that a recipient of the name from the name donor can refer to him as 'my father or grandfather.' Mönnig (1967) noted a similar case amongst the Pedi, where children are named after the paternal and maternal relatives to bring the forefathers or ancestors closer. Mohome (1972:172) reports a similar practice amongst the Basotho. This indicates, therefore, that in some traditions, names can form a chain that leads back across history to forgotten times and people. People who carry such names or people whose family members are linked to such names tend to feel uniquely empowered and, thus, different from their other relatives, because they are draped with identifying descriptions of honour. Usually, those who carry names of the pioneers would feel more empowered than those named after lesser known ancestors. Commemorative names can thus, often be used to manipulate power relations between people.

Besides commemorative names, in most communities, senior members, such as grandparents and traditional healers, give children names based on the circumstances surrounding their birth. These circumstances could be religious, political and cultural, or could be triggered by the condition of the mother or issues within the family or even the community, as Akinnaso (1980:279-280) indicates. Such a name is supposed to carry the seal or endorsement of the elders. This implies that any name given by the child's mother or father does not carry enough weight. The names that often are given are contentious ones and are used as a channel to communicate problems.

Thipa (1984:91) refers to such cases as 'rocking the boat', where children who are illegitimate are given names that are a constant reminder to their parents of their family circumstances. Thipa mentions names, such as Sebueng, meaning 'Don't say anything', Nthofela, meaning 'A mere thing', Tsietsi meaning 'Doubts', in Sesotho and Velaphi meaning 'Where do you come from?' in isiZulu. The names construct a discourse that reminds the parents of their sins and, at the same time, speaks indirectly to the children, and unfairly so. Usually, in the course of time, the parents of the children modify these names, where Sebueng becomes Bui, Nthofela becomes Ntho or Tonto, Tsietsi, becomes Tsitsi, Velaphi becomes Veli and Dideka becomes Didi; in order to lessen or dilute the pain. However, the reasons behind the naming remain, although not at a surface level.

Musere (1999:59-60) found that amongst the Baganda, children are given proverbial names to relay messages of cooperation, wisdom, intelligence, allegiance and warning on certain issues. Musere also noticed that some were used to 'communicate opinions of the name givers to others.'

These cases indicate that names are a form of discourse or interaction between the name-givers and their addressees.

In order to bring into focus the issue of power relations regarding names, the focus will now be on the notions of voice and identity which are noticed in the linguistic, historical, religious and cultural aspects of name-giving in Tshivenda.

\section{On the notions of voice and identity}

Bakhtin (Holquist [1941] 1981:95) points out that all texts, be they written or spoken, are fundamentally dialogic (Scollon et al. 2004:173). In this manner, the speaker answers or responds to what has gone before and can react in anticipation to what is to come. Scholars in this case speak of 'intertextuality' or point out that texts are polyvocalic or multi-voiced. Fairclough (Janks \& Ivanic 1992:95) identifies that when a discourse or voice is used elsewhere, we speak of 'discourse representation'. Another term used by Scollon et al. (2004:174) is 'voice appropriation'. On this they note:

On the one hand, all texts answer or respond to previously uttered texts while anticipating responses, and on the other hand, all texts are crafted out of borrowed language and thus in being uttered reflect both the utterer's voice and voices of those from whom s/he has borrowed the text. That is to say, all texts are uttered in multiple voices and in anticipation of polyvocal responses. (p. 174)

What has been noticed though, is that in most texts or spoken discourse, speakers have a tendency to adapt, appropriate or even transform texts to suit new situations. Hartman (1992:298) maintains that from this type of borrowing one is able to create texts that are able to construct authorial identities. Usually there is always some kind of relationship between the new discourse and its cultural, historical and institutional settings. According to Kamberelis and Scott (2004):

we seldom, if ever, create our own language styles and texts anew. Rather, we use the styles and texts of other individuals and groups with whom we wish to be affiliated, have power over, or resist. (p. 205)

What is stated above implies that when names are repeated, they carry the voices recorded earlier in history, like a celebration of a people's heritage or a cultural festival which could either be positive or negative. For instance, a 
commemorative name could create a discourse or voice that brings joy to someone, but can remind others of struggles of the past. The identities they create could be empowering to some in as much as they can be disempowering to others. In this type of constructing of discourse, people are able to notice the type of voice, where it comes from, and also why it has been appropriated in the form it appears. This view supports the process of naming and the effect names have when they are given to people or objects. It has been shown by scholars that names are reminders of conflicts and that the mere mention or sight of one could move people to act.

Further, Bakhtin (Holquist [1941] 1981:272) sees voices in discourse as expressing ideologies. This could be the reason why, especially through names, historical or cultural discourses are triggered. Ideologies are crucial means through which powerful people are able to dominate, control and manipulate the less powerful in order to maintain their positions and to perpetuate indirect power abuse and inequality. However, when the powerless realise this, they too use other voices strategically, to respond in order to resist or emancipate themselves, and then there is a collision of voices.

The issue of voice in emancipatory discourse will be dealt with using critical discourse analysis, which focuses on power relations between the powerful groups and the powerless ones.

\section{Critical discourse analysis}

Critical discourse analysis (CDA) focuses on how language or even the use or creation of names is used to re-produce and enact power relations through dominance, control, power abuse and the legitimisation of inequalities (Fairclough \& Wodak 1997; Van Dijk 2001). CDA is concerned with relations between language, power and ideology.

On the whole CDA is said to be biased towards the underdogs as they are the ones who are dominated, controlled, abused and suffer the inequalities. Here scholars see not just ideology but hegemony where oppression appears to be jointly produced (Cameron 2001; Fairclough 1992; Fairclough \& Wodak 1997; Janks \& Ivanic 1992; Van Dijk 2001). Ideologies are normally used to manipulate people who are being dominated, controlled and abused. Powerful people go on to use strategies to legitimise inequalities in such a manner that everything they do seems natural or legitimate. In the case of struggles of any nature, like disagreements and conflicts, language becomes a powerful weapon by which those with power impose their positions and views on others to strengthen their own social influence or power. This use of discourse or language tends to mirror the social positions of the powerful groups and their ideologies. Through naming, for instance, their ideologies are expressed (Fairclough \& Wodak 1997).

CDA studies or analyses involve discourse that reflects 'relationships of dominance, discrimination and control as manifested in language' (Fairclough \& Wodak 1997). This highlights the emancipatory potential of CDA. According to Titscher et al. (2000:146): CDA is concerned with social problems. It is not concerned with language or language use per se, but with the linguistic character of social and cultural processes and structures.

CDA focuses on the relations between social life or its problems and the role of discourse in social life, and in this case, tends to uncover the discriminatory and abusive use of language and goes on to 'empower the powerless, giving voice to the voiceless, exposing power abuse and mobilising people to remedy social wrongs' (Blommaert 2005:25). This is the reason why it is said to be deliberately biased towards the powerless, and this makes it what Van Dijk (2001:96) calls, 'discourse analysis with an attitude'.

The emancipatory agenda of CDA creates a conflict between the powerful group and the powerless, hence Foucault (1980) and Grillo (2000) see discourse as a site of a power struggle. When the powerful feel that their authorial voice is not gaining the upper hand, they increase their dominance; equally, when the powerless feel that their voice is diminishing, they too respond and eventually 'the two voices collide', as Bakhtin (1973:163, cited in Blackledge [2005:15]) asserts.

Foucault (1980) explains that power is exercised with intention. He stresses that wherever power is used, it is productive and useful in any society. Rabinow and Rose (1994:137) who worked on Foucault cite him as having noted that 'the exercise of power is not simply a relationship between 'partners', individuals or a collective; it is a way in which some act on others'. Foucault (in Rabinow and Rose 139) explains that wherever there are power relationships, it does not mean that those who are powerless will merely accept to be controlled by the powerful; instead, they come up with strategies to resist, hence emancipatory discourse.

\section{Methodology}

An important element is that critical discourse analysis is not some theory that deals with issues singlehandedly; some analysts, in fact, say that it is not a theory, but a school which brings theories or approaches into dialogue (Fairclough \& Wodak 1997; Van Dijk 2001, 2008). For this reason, therefore, in this study of names, the approach will be multidisciplinary, as other related approaches, such as morphology, ethnography of communication and critical discourse analysis will come into play. In forming names, linguistic knowledge and skills are important in order to achieve communicative competence and to reveal how power relations are realised.

This study will focus on a small number of names. The size of the sample is small in order to be easily managed. It was decided not to mention the names of the name-givers, addresses or even name-carriers; as most of them are very sensitive as evidenced from critical discourses. 
The names will be interpreted in terms of the number of voice appropriation strategies or practices suggested earlier by Bakhtin (1984), Kamberelis and Scott (2004), and also Scollon et al. (2004). Amongst these voice appropriation strategies are: hidden polemic, inner polemic, principalling and idealisation. Furthermore, the morphological structures of the names and pragmatic explanations will be given and, with others, the characteristics associated with the donors or earlier carriers will be given to show how they were created or chosen. Critical discourse analysis will be used to interpret power relations associated with the names.

\section{Hidden polemic}

According to Bakhtin (1984), a hidden polemic occurs in the following conditions:

[in] a dialogue of two persons in which the statements of the second speaker are omitted, [...] in such a way that the general sense is not at all violated. The second speaker is present invisibly, his words are not there [...]. (p. 197)

What happens here is that the name-giver is answering and responding to what his or her interlocutor has done or said. The name and its discourse are obvious, also to the interlocutor(s), but they do not answer back in normal speech.

Amongst Africans in general and amongst the Vhavenda in particular, in families the elders, especially grandparents, wield enormous power over their children, be they sons or daughters or daughters-in-law. Power relations everywhere shape the use of language as the elderly name their grandchildren. See the cases below:
Mushayathoni:
'One who has no shame.'
Morphological structure: $\mathrm{Mu}$-cl.1 (person) +-verb root-shay-(lack)-
+ nominal stem-thoni (shame).
Basic meaning: One who has no shame or is not ashamed.

Pragmatic explanation: The grandmother decided to name the new baby girl Mushayathoni after her daughter-in-law decided to cut down all the mealies in the grandmother's field. The daughter-in-law seemingly did not take kindly to being told time and again to stop quarrelling with the co-wives in the family. The old lady considered this indicative of a lack of manners and replied with the name Mushayathoni. The hidden polemic is expressed in that whilst the child carries the name, the target is her mother, the accused who is the mother is not directly mentioned, neither is the shame that is being talked about. However, it is clear that there is a dialogue between the given name and the absent activity or utterance by the daughter-in-law.

Ndidivhani 'One with very little knowledge.'

Morphological structure: $N d i-(\mathrm{I}) 1^{\text {st }}$ person Concord (for pronoun I) + verb stem - divha- + interrogative morpheme (suffix)-ni (what from mini).

Basic meaning: I have very little knowledge.
Pragmatic explanation: In this case, the father was very stubborn and wanted to give the impression to everyone that he was capable and required nobody's advice. The elders came up with the name Ndidivhani or 'I have very little knowledge' for his newly-born daughter. The name is rather sarcastic, as the first person pronominal Ndi or ' $\mathrm{I}$ ', does not refer to the speaker or name-giver, but to the father of the child who is the addressee. The hidden polemic is expressed in the indirect reference to the father and also the implicit reference to the little knowledge that he has.
Thinawanga
'I have no relatives of my own.'
Morphological structure: Negative $1^{\text {st }}$ person pronominal concord Thi- +verb stem $n a$ - (have) $+1^{\text {st }}$ person possessive-wanga (mine). Basic meaning: I have none of my own.

Pragmatic explanation: The name Thinawanga came into the picture when the grandmother noticed that she was always shunned by both the father of the child who is her son, and by her daughter-in-law. As a result, she felt isolated and expressed this feeling through the name. The hidden polemic is expressed in the implicit criticism directed at her son and daughter-in-law for isolating her. The name does not refer directly to any family member or to the issues that she is complaining about. However, it is from the given discourse in the name that the absent one (discourse) is understood.
Azwiambiwi
'Do not mention'
Morphological structure: Negative formative $A-+$ cl. 8 concord -zwi- (issues) + verb root-ambiw-(talk about) +- terminative- $i$.
Basic meaning: Do not speak about it.

Pragmatic explantion: Azwiambiwi was given to a girl child whose mother happened to be very emotional and pugnacious at the slightest provocation. So, for the sake of peace whenever she did something wrong, they merely looked at her without saying anything. The name is very general and ambiguous due to the use of the concord par excellence $-z w i-{ }^{\prime} i t^{\prime}$. It is this element that brings on the hidden polemic because the issues at stake are not mentioned. The concord $z w i^{\prime}$ it' refers to these issues which although not mentioned are nevertheless understood or known by the addressees.

These examples show that names sometimes tend to reprimand, alert, wag a finger at and threaten. They reflect messages or discourses that produce or reproduce indirect dominance, control, power, and in some cases, power abuse on the part of the elderly. The names express the lack of any significant power, and show instead that they have only symbolic power left.

\section{Inner polemic}

It was also noted that the younger generation decided to answer their elders by giving their children names that answer or respond to the names first given to the children by the elders. In this case, the voice appropriation fits with what Bakhtin calls 'innerly polemic'. By an inner polemical word, Bakhtin (1973:163) refers to a 'word with a sideward glance at another person's hostile word, which possesses 
enormous style-determining significance'. Blackledge (2005:15) adds that, in such cases, the addressee becomes 'aware of a contradictory utterance and responds to it with cutting remarks ("jabs and needles")'. The names below indicate this:

\section{Nditsheni 'Leave me alone.'}

Morphological structure: First person singular pronoun $n-(-n e)$ 'me'+ verb stem -litsha (-e) +second person plural pronoun -ni (you).

Basic meaning: Leave me alone.

Pragmatic explanation: Nditsheni was given to a baby boy whose mother conceived him with a married man. Her parents quarrelled with her as she had caused untold misery in another family, but she became stubborn and answered them through the name of the same child, who she named Nnditsheni 'Leave me alone'. The speaker is responding directly to people who can hear her as the pronominal $-n i$ 'you' indicates. The cutting response she gives, warns them to back off. In essence, the indirect reference to the issue at stake makes circumstances worse. They know that they have been warned.
Azwifarwi
'Don't touch.'
Morphological structure: Negative formative $A-+$ class 8 concord-zwi (they/things) + verb root -farw- (touch) +terminal vowel $-i$.
Basic meaning: They (things) should not be touched.

Pragmatic explanation: The father of the child explained that his mother was very dominating and wanted to rule his household. Her word, as he put it, was final and he answered her through the name, Azwifarwi 'do not touch', because he wanted to be independent. Apparently over the years the name carrier became aware of the reasons behind his name and subsequently decided to stress that he should be called by his other name Maanda, 'power'. The change of name implies that each time he was called by it he felt tormented.

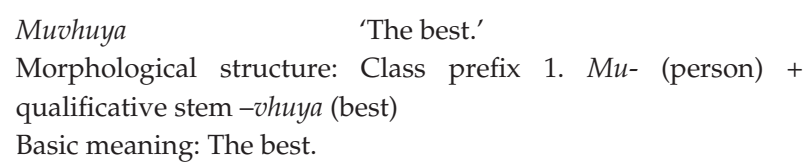

Pragmatic explanation: Muvhuya was born from the cohabitation of teenagers. This led to people stigmatising them for transgressing the taboo against teenage intercourse. As a way of matching their criticism, the mother decided on the name Muvhuya, 'The best, whatever you say'. Although the child carries the name, its meaning has a dual purpose, as whatever is good is directed at both the mother and child. In other words, no one should condemn her for the teenage pregnancy or see the child as a mistake as both are 'the best'. This indicates that she was warding off all sorts of criticisms from known addressees.

On the whole, one notices in these names a subtle element of responding or answering to the elder's voice in the names that reflect innerly polemic discourse. Here the parents of the children seem to tell the elders that they also have their own world view. The responses, by the parents of the children to the elderly and others concerned, bring forth a clash of voices; however, the battle is very subtle.

\section{Principalling}

In the case of principalling, according to Scollon et al. (2004:194), the speaker or name-giver takes the responsibility for the creation of the discourse. Kamberelis and Scott (2004) see it as 'adoption'.
Odaho
'The one who has come'
Morphological structure: Third person pronominal concord singular O- (s/he/one) + verb stem-da- (came) +-relative suffix-ho. Basic meaning: One who came or has come. (p. 214)

Pragmatic explanation: Odaho, meaning 'the one who has come', received her name from her father because he believed that children come from God and people do not make them. This was after some people argued that children are not to be named before their birth as it was a taboo, the more so, as the sex of the child was not known. The father stuck to the name for either a boy or a girl. A girl was born who carries the name with pride, as the father anticipated:
Unarine
'He is with us.'
Morphological structure: Third person pronominal concord singular $U$ - $(\mathrm{He} / \mathrm{God})+$ copulative $-n a$-(being in presence) + second person pronoun plural-rine (us).
Basic meaning: (God) or He is with us.

Pragmatic explanation: The child received the name as a joint expression of relief by both parents as the mother became ill during her pregnancy. They had feared that one of them would die, but both survived. Some relatives had sought to interfere by suggesting that they use some medical potions to protect the unborn child, but both parents refused, sticking to their faith.

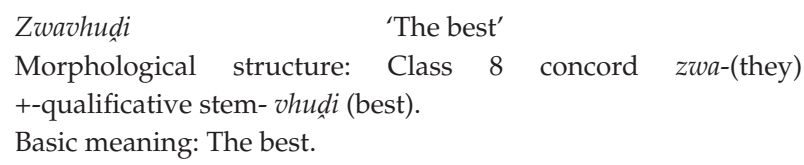

Pragmatic explanation: Zwavhudi was named by both her parents, who in their partnership, noticed that when one has accepted God's salvation, everything else that follows, will turn out for the best - including their child. The mother faced challenges, as some relatives did not like her husband, and in defiance she gave the child the name Zwavhudi, meaning 'all will turn out for the best'.
Akhae 'The matter is in God's hands.'
Morphological structure: Class 6 concord $A$ - (The matter) + instrumental-kha- (with/at) + third person pronoun singular- $e$ (ne) Him or God.
Basic meaning: It, or the matter, is in God's hands.

Pragmatic explanation: The mother became pregnant at a very early age which meant that she had to miss a year of her studies. In the name Akhae, she acknowledges her mistake and encourages any person who wants to know God to do the same. In other words, her bringing a baby into this world at a tender age has nothing to do with anyone, as it is 
between herself and God. Put differently, whoever wants to know anything about the child must ask God.

Most of these names break with the past, leaving no trace of family quarrels, disagreements and conflicts. The names praise God, make references to God, talk about the parents' relationship with him, create good images, refer to the environment, and express appreciation of the environment, marriage and good neighbourliness.

In another case, one of the parents felt left out within the family, as children were only given names from one side, mostly the father's, and in the process this parent decided, despite the odds, to name one of the children from her language group which is Tshivenda. She then decided on the name Mukondeleli or 'one who perseveres'. In Mukondeleli, the mother felt left out after all the other children were given Sotho names belonging to the husband's language and culture. She decided to name the child after her maternal grandmother who was an inspiration in her life.

Identifying descriptions:

1. Mother who kept the family together.

2. Prayerful woman who was a pillar of strength to many.

3. Generous woman who clothed the poor.

4. Beautiful mother whose beauty is reflected in my daughter.

There are cases where parents crossed over and gave their children names from other languages and cultures. For instance, a Muvenda father gave his daughter the name Nkhensani (a Xitsonga name). He said that he decided on the Xitsonga name in honour of his mother a Mutsonga or Shangaan who was married into a predominantly Vhavenda community, where she appeared isolated and he decided to make her presence felt through the name of his child.

Identifying descriptions.

1. I see my mother in her.

2. My mother was a role model.

3. She loved Vhavenda regardless of being a Mutsonga or Shangaan.

The names show that some parents will try their best to do the unusual. Instead of sticking to the marital family names in Sotho and Tshivenda, the mother decided on a Tshivenda name, Mukondeleli, because she is a Muvenda and the father chose a Xitsonga name, Nkhensani, instead of a pure Tshivenda name. Both decided to give their children names that link them to their origins and history. The names are chosen out of pure appreciation of other languages and cultures, thereby demystifying the myth that Africans do not love and appreciate one another.

\section{Idealisation}

Some names are more commemorative than others, focusing on the good characteristics of the name carrier. This is called idealisation, which 'refers to the appropriation of another's discourse and transformation of it to create a kind of utopian ideal discourse' (Kamberelis \& Scott 2004:216).

Examples of names that were given to children by their parents are:

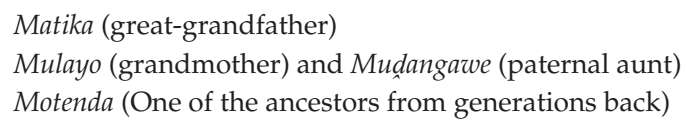

What is remarkable in these cases is that the parents' names are overlooked or avoided. However, the choice indicates that the parents aspire to see their children taking after people linked to their mothers or fathers, to build bridges between the generations.

In other cases husbands and wives from two different language groups and cultures idealise good partnerships within their families or marriage through the names of their children. In such cases a child would carry names from both the father's and mother's side, or the first born would receive a name from the father's language and the second from the mother's. See the names below:

Onndisa 'He/God has looked after me' (from the father's language, Tshivenda) and Phemelo,'Shield' (from the mother's language, being Sotho).

$\begin{array}{ll}\text { Mpho } & \text { 'Gift' (from the father's language, Tshivenda). } \\ \text { Lerato } & \text { 'Love' (from the mother's language, Sotho) }\end{array}$

In the above example, each child carries a name from either the father's or the mother's language, to balance issues. These names are proof that men do not make decisions alone, but that women are also recognised as partners in the building of a family.

There has also been another development in royal families or families associated with royalty amongst the Vhavenda, where children are named after their legendary forefathers and pioneers, such as Bele, one of the forerunners of Vhasenzi, or Mokgadi, after one of Makhado's wives.

Bele

Identifying descriptions:

- An earlier forerunner of the Vhavenda.

- A trusted prince from an earlier Vhavenda dynasty.

- A fearless leader who kept the Vhavenda together.

Mokgadi

Identifying descriptions:

1. Daughter of Ramokgopa, the leader of the Batlokwa.

2. King Makhado's wife.

3. Mother of Maelula, one of king Makhado's sons.

4. The royal link between the Ramokgopa and Ramabulana royal families.

Madala, a name of an earlier ruler within the Mashau royal family. 
Identifying descriptions:

1. Forefather of the Mashau dynasty.

2. The main link between the Sotho and Vhavenda vha ha Mashau.

3. A legendary figure who was a contemporary of king Makhado.

4. One of the Mashau royal family members who established the initiation school at Tshamatangwi which Makhado attended.

These commemorative names are given to children in order to record history. The name-givers seem to recognise their heroes and forerunners in them. It should be noted that not every child in these royal families is entitled to such names as they are linked to power and the throne. However, there are many these days, as in the case of the names above, who feel that they, too, have a share in the throne and who decide nevertheless to give their children these very names. This practice tends to express a subtle protest against the elders who set such names aside for those who inherit the throne.

\section{Interpretation}

This study has shown amply that, although names are usually used to refer to children and provoke their response, in reality it is the elders and the children's parents who are speaking to each other. In doing this, they create hidden voices and identities around the name-carriers who are blameless or innocent children. At an underlying level, the negative image or identity created belongs to the elders and the parents, but also affect the children. It has been found that both the parents, who are the addressees, and children, who end up being the name-carriers, become uneasy with the voices and negative images created.

Names as discourse create voices that are dialogic, or answer or respond to what has gone before or is taking place, and at times react in anticipation of what is to come. Voices are traditional, where they continue from generation to generation or express what is found in the traditions of the people. This is the case where names create ideological voices. However, they can also be creative, where the name givers, besides borrowing from others, can create or re-create names from the surrounding environment and come up with what could be seen as a kind of declaration of independence.

In this study, the voice of tradition is heard in the hidden polemic in the names the children are given by the elders amongst them great-grandparents, grandparents and aunts (Blacking, 1964:18-19; Stayt 1931:88-89). The ideology expressed through this voice is indirectly dominant, forceful and coercive. There is indirect dominance and rule by force which constitutes an element of othering (Riggins 1997; Tekin 2010; Van Dijk 1997). However, this voice of tradition is also displayed by the parents of the children through an inner polemic, where they seem to be responding to the elders. They, too, become resistant and forceful, although indirectly, thereby making the names a site of struggle, as Grillo (2000) asserts. Through these names, the parents express power, although indirectly, and take on the elders in the battle over the surface identities of the children, but really intend taking on the underlying ideologies which paint them negatively. It was noted that in such cases, as children who are the namecarriers feel burdened by the names, the parents replace or shorten them in order to create positive identities.

The very same voice of tradition has been displayed in an apparently positive manner, for instance in the case of principalling, especially where children are given names from other languages to honour parents. These names seem to have been chosen strategically to build linguistic, cultural, historical and diplomatic bridges and to soften relations between the elders and the parents of the children. However, a subtle element of protest is also noticeable in these names. The voice of tradition has also been taken into account in some cases of idealisation, where children have been named after certain elders, such as forefathers, great-great-parents, grandparents, aunts, uncles and also historical figures. It has been stated that, in this case, tradition has been strategically manipulated by the parents of the children because they did not want their children to be named by the elders, or after some unfavoured figures. As power can be manipulated, the young generation are able to use their power to give names and to speak to the elders without fear. This is where Foucault (1980) argues that power is exercised with intention.

The creative voice was noticed with principalling. This voice is seen as that singularity of utterance which is sought by writers as an emblem of both individuality and artistic achievement ...' (Scollon et al. 2004:176). The names seem to create various voices which, in turn, construct different although unique and positive identities. In these cases parents decide on a voice that she or he wants to hear and an identity with which she or he wants to associate. For this reason, they sit, observe and read history, religion, education and any element within their socio-cultural environment, and then gently and freely create and recreate new names that produce new and pleasing identities. Even in these cases, however, there is a veiled element of protest by the parents of the children.

The creative voice was also noticed with idealisation where parents of the children created new voices from the environment and also adopted commemorative names from history. In whatever name is created, there is an element of partnership between the parents or name givers. This is like saying, 'we are equal,' because the names created and recreated by the new parents, produce desired voices and fitting identities. From history, they use celebrated forerunners in their families and communities. All these voices construct positive identities - identities of choice and of freedom. However, in all the names, the younger generation are nicely and diplomatically applying an element of othering to the elders, something of which the latter are aware, but keep their distance from this process, for the sake of peace. 
It must be said that, from the names discussed, the reasons or circumstances behind the naming seem to be very functional as was the information content from the identifying descriptions or characteristics. However, when interpreted within context, names have meaning and construct discourse between people as they interact through the names.

\section{Conclusion}

As stated above, names may appear to be very small linguistic elements, but in fact code much information about events, history, culture, heritage and goings-on in families and communities. It is important to note that in any discourse, there is a speaker and an addressee(s) on a particular topic. When children are given names, such names construct new discourses with multiple-voices, and these, in turn, create and recreate multiple identities.

This study was decided upon after noticing some changes in the naming of children amongst the Vhavenda, especially the naming of those whose names are free from all sorts of disagreements, quarrels and conflicts, although in some veiled protest is found. The names that were chosen by the elders seem to be very problematic to the parents of the children because they do not like either the identities created for them and their children, nor do they like to hear the voices heard through this naming. The names chosen by the parents show an attempt to break not only with the past, but also with the apparent indirect dominance and control of the elders.

What has also been noticed, from the names of children given by their parents, is the presence of some form of a struggle intended, by the name givers, to liberate or emancipate themselves from the control of the elders, especially when they continue to live with them. However, there are those who decide to work far away from home or look for a new place in which to live. When they are away they feel emancipated but, in the event of a child being born, they know that they must report this event, as the child belongs to the family. By way of empowering themselves, they only report the child's birth once the child has already been named and rarely ask for the opinions of the elders.

From the discussion above, it is clear that in most cases when the elders name their grandchildren, they want to communicate some displeasure by making their voices heard. On the other hand, when the parents name their children, they react to the naming methods of their elders. As a result of the conflicting voices that are created by both groups, the parents take pains to adopt certain of the names of some elders for their children, especially those of greatgrandparents. These result in creating positive voices that recreate different images or identities.

Cases such as principalling and idealisation show how parents attempt to make peace, in many ways, with their elders and also take a stand to show their independence and self-redemption. What one reads in these names is some form of response to something that was said or done at an earlier time, and the present discourse is a re-contextualisation thereof. In other words, you can read a dialogue from the explicit utterance or name that you see and hear. Besides, there is some sort of a blow that is directed towards the addressee(s) whom you may or may not see (Bakhtin 1984). This means that from the name it is easy to see the struggle between the elders and the younger parents.

The formation or creation of names shows that this is accomplished within context. This, therefore, means that morphology should be studied and taught in context. It also brings into play the issue of an inter or multidisciplinary approach, as in their creation, there is also onomastics, pragmatics, discourse analysis, ethnography of communication and critical discourse analysis.

\section{Acknowledgements Competing interests}

The author declares that he has no financial or personal relationships which may have inappropriately influenced him in writing this article.

\section{References}

Akinnaso, F.N., 1980, 'The sociolinguistic basis of Yoruba personal names', Anthropological Linguistics 22(7), 275-304.

Arno, A., 1994, 'Personal names as narrative in Fiji: Politics of the Luana Onomasticon', Ethnology 33(1), 21-34. http://dx.doi.org/10.2307/3773972

Bakhtin, M.M., 1973, Problems of Dostoevsky's poetics, 2nd edn., transl. R.W. Rostsel, Ardis, Ann Arbor.

Bakhtin, M.M., 1984, Problems of Dostoevsky's poetics, transl. C. Emerson, University of Minnesota Press, Minneapolis.

Blacking, J., 1964, Black background: The childhood of a South African girl, AbelardSchuman, London.

Blackledge, A., 2005, Discourse and power in a multilingual world, John Benjamin, Philadelphia.

Blommaert, J., 2005, Discourse, Cambridge University Press, Cambridge. http:// dx.doi.org/10.1017/CBO9780511610295

Cameron, D., 2001, Working with spoken discourse, Sage Publications, London.

Donnelan, K.S., 1985, 'Proper names and identifying descriptions', in A.P. Martinich (ed.), The philosophy of language, pp.236-268, Oxford University Press, Oxford.

Fairclough, N., 1989, Language and power, Longman, London.

Fairclough, N., 1992, Discourse and social change, Polity Press, Cambridge.

Fairclough, N. \& Wodak, R., 1997, 'Critical discourse analysis', in T.A. Van Dijk (ed.), Discourse as social interaction, pp. 259-284, Sage Publications, London.

Foucault, M., 1972, The archaeology of knowledge, Routledge, London.

Foucault, M., 1980, 'Truth and power', in C. Gordon (ed.), Power/knowledge: Selected interviews and other writings 1972-1977, pp. 109-133, Pantheon Books, New York.

Frege, G., 1985, 'On sense and meaning', in A. P. Martinich (ed.), The philosophy of language, pp. 200-212, Oxford University Press, Oxford.

Grillo, E., 2000, 'Two dogmas of discourse analysis', in F. Grillo (ed.), Power without domination: Dialogism and empowering property of communication, pp. 3-41, John Benjamin, Philadelphia.

Hartman, D.K., 1992, 'Intertextuality and reading: The text, the reader, the author and the context', Linguistics and Education 4, 295-311. http://dx.doi. org/10.1016/0898-5898(92)90005-H

Holquist, M. (ed.), [1941] 1981, The dialogic imagination, four essays by Bakhtin, M, University of Texas Press, Austin.

Janks, H. \& Ivanic, R., 1992, 'Critical language awareness and emancipatory Discourse', in N. Fairclough (ed.), Critical language awareness, pp. 305-331, Longmans, London.

Kamberelis, G. \& Scott, K.D., 2004, 'Other people's voices: The coarticulation of texts and subjectivities', in N. Shuart-Faris \& D. Bloome (eds.), Uses of intertextuality in classroom and educational research, pp. 201-250, Information Age Publishing, Greenwich.

Litosseliti, L., 2010, Research methods in linguistics, Continuum International Publishing Group, London.

Mohome, P.M., 1972, 'Naming in Sesotho: Its sociocultural and linguistic basis', Names 20, 171-185. http://dx.doi.org/10.1179/nam.1972.20.3.171 
Mönnig, H.O., 1967, The Pedi, Van Schaik, Pretoria.

Musere, J., 1999, 'The visitor in some proverbial names of the Baganda', Nomina Africana 12(1/2), 59-71.

Rabinow, P. \& Rose,N., 2003, The essential Foucault: Selections from works of Foucault 1954-1984, New Press, New York.

Riggins, S.H., 1997, The language and politics of exclusion: Others in discourse, Sage Publications, London.

Russell, B., 1985, 'Descriptions', in A.P. Martinich (ed.), The philosophy of language, pp. 213-219, Oxford University Press, Oxford.

Saarel-Maunumaa, M.M., 1999, 'Name sharing in the system of Ovambo Namibia', Nomina Africana $13(1$ \& 2), 35-45.

Searle, J.R., 1985, 'Proper names', in A.P. Martinich, (ed.), The philosophy of language, pp. 270-291, Oxford University Press, Oxford.

Sengani, T.M., 2008, 'Strategic discourse in names: A critical discourse analytical interpretation with special reference to Tshivenda naming practices', Unpublished $\mathrm{PhD}$ thesis, University of Limpopo, Polokwane.

Scollon, R., Tsang, W.K., Li, D., Yung, V. \& Jones, R., 2004, 'Voice, appropriation and discourse representation in the student writing task', in N. Shuart-Faris, \& D. Bloome (eds.), Uses of intertextuality in classroom and educational research, pp 173-199, Information Age, Greenwich.
Stayt, H.A., 1931, The Bavenda, Oxford University Press, London.

Tapscott, B.L., 1968, 'Proper names: How they are and what they mean', PhD thesis, University of Washington, D.C.

Tekin, B.C., 2010, Representations and othering in discourse: The construction of Turkey in the EU context, John Benjamin Publishing, Amsterdam. http://dx.doi. org/10.1075/dapsac.39

Thipa, H., 1984, 'What shall we call him?', SAJAL 1, 84-99.

Titscher, S., Meyer, M., Wodak. R. \& Venter, E., 2000, Method of text and discourse analysis, Sage Publications, London.

Tonkin, E., 1965, 'Jealous names, civilized names: Anthropology of the Jlao Kru of Liberia', Man 15, 643-664.

Van Dijk, T.A., 1997, 'Political discourse and racism: Describing others in Western Parliaments', in S.H. Riggins (ed.), The language and politic $s$ of exclusion: Others in discourse, pp. 31-64, Sage Publications, London.

Van Dijk, T.A., 2001, 'Principles of critical discourse analysis', in M.S. Wetherell \& S.J. Yates (eds.), Discourse theory and practice: A reader, pp. 300-317, Sage Publications, London.

Van Dijk, T.A., 2008, Discourse and power, Palgrave Macmillan, New York.

Ziff, P., 1960, Semantic analysis, Cornell University Press, Ithaca. 